\title{
Studies on Management Practices and Constraints of Back Yard Chicken Production in Selected Rural Areas of Bishoftu
}

\author{
Hunde Weyuma ${ }^{1}$, Harpal Singh ${ }^{1}$ and Mulisa Megersa ${ }^{2^{*}}$ \\ ${ }^{1}$ Addis Ababa University, College of Veterinary Medicine and Agriculture, Bishoftu, Ethiopia \\ 2 Jigjiga University, College of Veterinary Medicine, Jigjiga, Ethiopia
}

*Corresponding author: Mulisa Megersa, Jigjiga University, College of Veterinary Medicine, Jigjiga, Ethiopia, Tel: +251924 008 984; E-mail: mulisam38@gmail.com Rec date: May 09, 2015; Acc date: Jul 16, 2015; Pub date: Jul 18, 2015

Copyright: $\odot 2015$ Weyuma H, et al. This is an open-access article distributed under the terms of the Creative Commons Attribution License, which permits unrestricted use, distribution, and reproduction in any medium, provided the original author and source are credited.

\begin{abstract}
This survey was conducted with the aim of assessing the flock characteristics, management practices and performance of indigenous chickens kept under backyard chicken production system from November 2013 to May 2014 in rural areas of Bishoftu, East Shewa, and Ethiopia. A total of 160 selected respondents were included in the study from four purposively selected kebeles viz. Filtino, Dalota, Kality and Gote. An overall average flock size (Mean \pm SD) was $19.9 \pm 7.9$ birds in the study area. About $35 \%$ of the respondents provide separate house to their birds. Majority of the respondents $70 \%$ in study area were using scavenging with additional supplements, out of which $56.3 \%$ of respondents were using food left over, frushika, maize and sorghum and $13.7 \%$ of respondents were using maize and frushika. Tap water was a major source in Dalota (100\%) and Gote $(67.5 \%)$ whereas river water accounts $62.5 \%$ as water source in Kaliti kebeles. About $55.6 \%$ of respondents use plastic ware for watering their birds. Major source of chicks was natural hatching (46.87\%). Overall mean performance of the indigenous chicken for age at first lay, number of eggs laid/hen/clutch, numbers of clutches/hen/year, number of eggs laid/hen/ year, number of eggs incubated/hen/clutch, number of eggs hatched/hen/year, hatchability on the basis of eggs incubated and chicken mortality to an age of 8 weeks in the study area were found as $5.49 \pm 0.8$ months, $13.18 \pm$ 3.5 eggs, $3.30 \pm 0.5$ clutches, $44.20 \pm 9.6$ eggs, $10.92 \pm 3.1$ eggs, $28.42 \pm 6.7$ eggs, $72.10 \pm 5.5 \%, 27.52 \pm 4.7 \%$ respectively. The hatchability and mortality were significantly different $(p<0.05)$ among four kebeles under study. The mortality of chicken was observed as major constraint in backyard chicken production in the area of study followed by diseases, predation and improper veterinary service at village level. Therefore, efforts should be geared towards the improvement of health and management practices to improve rural backyard chicken production.
\end{abstract}

Keywords: Poultry; Management; Performance; Constraints; Bishoftu

\section{Introduction}

The word poultry refers to all domesticated birds kept for the production of eggs and meat for human consumption including domestic fowl (chicken), turkeys, ducks, geese, guinea fowls, ostriches and others [1]. Despite the rapid development of commercial poultry production systems worldwide, it has been estimated that more than $80 \%$ of the global poultry population occurs in traditional familybased production systems and contribute up to $90 \%$ of the total poultry products in many countries [2]. In many developing countries, particularly Africa, poultry production in rural and peri-urban areas is based on traditional scavenging systems. It is estimated that about $80 \%$ of the Africa's poultry population is found in traditional production systems [3]. The system is characterized by a family ownership of the birds. The birds are then left to scavenge to meet their nutritional needs. The feed resources vary depending on local conditions and the farming system [4].

Poultry production is deeply embedded in Ethiopian society kept by all strata of society from the landless rural poor to the well off in the cities $[5,6]$. In the Ethiopian context poultry effectively means domestic chicken. Out of a total of 44.89 million chickens in Ethiopia, the traditional back yard poultry production accounts for about $98 \%$ mainly indigenous birds (96.9\%) [7] and contributes to more than $90 \%$ of the national chicken meat and egg output [8]. Indigenous chickens are nine descriptive breeds closely related to the Jungle fowl and vary in color, comb type, body conformation and weight. There is no separate poultry house and chickens live in family dwellings. The mean annual egg production of indigenous chicken is estimated at 60 small eggs with thick shell and deep yellow yolk color [9].

In Ethiopia poultry production systems show clear distinction between traditional low input system on the other hand and modern production systems [1]. The traditional poultry production system comprises of the indigenous dwellings together with human beings. There is no purposeful feeding of chicken and scavenging is almost the only source of diet. There is no designed selection and controlled breeding. It is by natural incubation and brooding that chicks are hatched and raised all over the rural Ethiopia. Prevalence of predators in the area, such as birds of prey, pets and some wild animals, all of which are listed as the major causes of premature death of chicks in Ethiopia. Diseases are the most important cause of economic losses since vaccination occurs only in response to an outbreak in the traditional poultry production system. The modern poultry sub-sector comprises of the small scale intensive and large scale commercial production systems. There are several private large scale commercial poultry farms in and in the vicinity of Addis Ababa, the majority of which are located in Bishoftu, Elfora, Alema and Genesis are the top 3 largest commercial poultry farms with modern production and processing facilities [10].

Traditional production system is advantageous due to free feed resources in the surrounding environment and kitchen leftovers, use 
of local breeds that are adapted to their environment and preserved ability to incubate and brood naturally. However, poor reproductive performance, poor growth rates, diseases, mortality, predation and low level of literacy among farmers are some of the major constraints in backyard chicken production [11]. To date, there are limited studies conducted in rural area of Bishofu targeting comprehensive description of the flock characteristics, production performance, associated constraints and management practice of backyard chicken in rural communities. Therefore this study was done with the objectives to characterize the flock structure and management practices, evaluate the productivity and in order to identify the prevailing constraints of backyard chicken production in the rural areas of Bishoftu.

\section{Materials and Methods}

\section{Study area and animals}

The study was conducted in selected rural areas of Bishoftu. All backyard rural poultry kept by the farmers of the study were included for this survey. Bishoftu is located 45 kilometers south east of Addis Ababa. The area is located at $9^{\circ} \mathrm{N}$ latitude and $40^{\circ} \mathrm{E}$ longitudes at an altitude of 1850 meters in central high land of Ethiopia. Study area includes Filtino, Dalota, Kaliti and Gote Kebeles of Bishoftu, East shewa zone, Ethiopia. It has an annual rainfall of $866 \mathrm{~mm}$ of which $84 \%$ is in the long rainy season (June to September). The dry season extends from October to February. The mean annual maximum and minimum temperatures are $26^{\circ} \mathrm{C}$ and $14^{\circ} \mathrm{C}$ respectively, with mean relative humidity of $61.3 \%$ [12]. Farmers in the vicinity of Bishoftu use a mixed crop and livestock farming system. Moreover, Bishoftu and its surrounding have variable and yet representative agro-ecologies of the country. These agro-climatic zones are inhabited with different plant and animal species [13].

\section{Study design and sampling procedure}

The survey work was carried out from November 2013 to May 2014. A total of 160 households, made up of 40 households each from Filtino, Dalota, Kaliti and Gote kebeles, were purposively selected. The selection of kebeles were carried out based on the accessibility easy of logistic and nearness to Bishoftu town. These four kebeles were approximately $8 \mathrm{kms}$ apart and systematic random sampling method was employed to select each household within the kebeles. During the study period only those farmers who owned chickens and were willing to participate in this study were considered.

\section{Data collection}

Data of households were collected by using semi-structured questionnaire and individual interview in order to obtain quantitative data. Direct observation of flocks, feeding and watering practices and poultry houses was carried out during the survey period. Information regarding the types of poultry reared, flock size and composition, production and reproduction performance, management practices, provision of additional feed, vaccination, use of modern medication and constraints of backyard chicken production system were recorded using the questionnaire survey.

\section{Data management and analysis}

The data were entered using Microsoft excel spreadsheet and analyzed using SPSS (Version, 20). Descriptive statistics were employed for describing management practices in each kebeles. Differences in productive performances were compared using means generated from one-way ANOVA.

\section{Results and Discussion}

\section{Household characteristics}

The observations recorded for household characteristics for sex ratio in respondents (Figure 1) revealed higher proportion of female respondents than males in all four kebeles under study. This reflected due to the fact that village backyard chicken production is mostly managed by females. Several previous surveys have indicated similar observations to this study [14-17]. However, nearly equal proportion of males (49.5\%) and females (50.5\%) have been reported in the South part of Ethiopia [18]. Analysis of educational status (Figure 2) observed under the present study revealed that on overall basis about $37 \%$ of the respondents in the study area were illiterates and this observation was in agreement with the report of Desalew et al. [17] who has observed about $33.4 \%$ of the respondents in Lume district were illiterates. However, a better education status with only $6.9 \%$ of illiterate was reported from south part of Ethiopia [18].

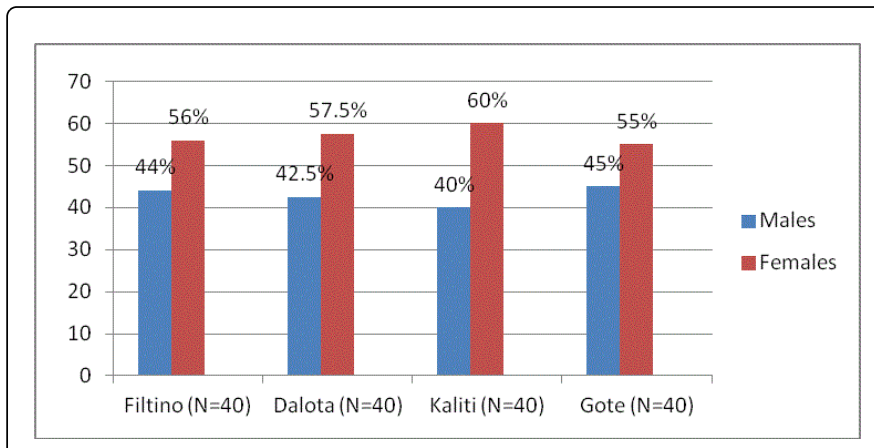

Figure 1: Sex ratios of respondents in four kebeles in study area.

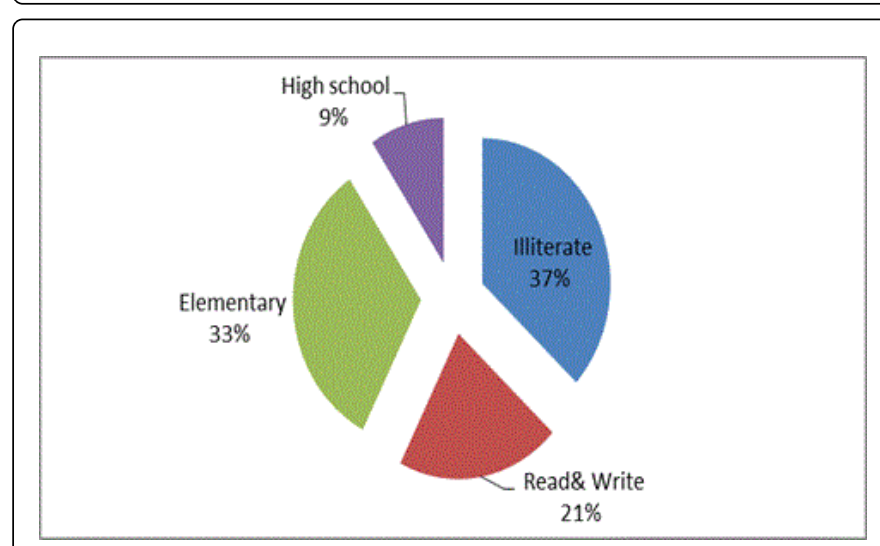

Figure 2: Educational level of the respondents of the study area.

\section{Flock size and structure}

The overall mean flock size per household (Table 1) was 19.9 and ranged from 5-49 in the present study. This finding is in consistent with the reports from Philippines [19] and Uganda [20] who reported 
Citation: Weyuma H, Singh H, Megersa M (2015) Studies on Management Practices and Constraints of Back Yard Chicken Production in Selected Rural Areas of Bishoftu. J Veterinar Sci Technol S12: S12-003. doi:10.4172/2157-7579.1000S12-003

Page 3 of 9

the mean flock sizes of 19 and 18 for village chicken production system, respectively. However, the present flock size is higher than the reported flock size of 9.2 by Mekonnen [18] in southern part of Ethiopia, 7.1 by Halima [21] in northwest Ethiopia, 8.8 by Asefa [22] around Hawassa and 6.2 by Meseret [14] in Gomma Wereda, Jimma Zone, Ethiopia. In contrast, the mean flock size recorded in this study was lower than the mean flock size of 22 in Sudan, for village chicken production system [23]. The backyard indigenous chicken population of study areas were dominated by chicks $(9.9 \pm 4.98)$ followed by hens (3.9) which was higher than 3.8 and 2.5 the corresponding figures for chicks and hen respectively reported by Mekonnen [18] in southern part of Ethiopia. The present result revealed mean of $1.8 \pm 1.5$ and 2.0 \pm 1.3 cocks and cockerels which is the lowest in flock size. The lower proportion of the cockerels and cock observed within the indigenous chicken population in this study was in agreement with report of Meseret [14] and this might be attributed to the selling of cockerels and cocks. Flock size and composition vary over time; however, it is a function of disease incidence, predators and the occurrence of festivals which induce high rates of off-take through household consumption and sale $[24,25]$.

\begin{tabular}{|c|c|c|c|c|c|c|c|c|}
\hline \multirow[t]{2}{*}{ Kebeles } & \multirow[t]{2}{*}{ Sample size(n) } & \multicolumn{7}{|c|}{ Flock structure } \\
\hline & & $\begin{array}{l}\text { Chicks } \\
0-8 w k\end{array}$ & $\begin{array}{l}\text { Pullets } \\
9-20 \text { wk }\end{array}$ & $\begin{array}{l}\text { Cockerels } \\
9-20 \mathrm{wk}\end{array}$ & $\begin{array}{l}\text { Hens } \\
>20 \mathrm{wk}\end{array}$ & $\begin{array}{l}\text { Cocks } \\
>20 \mathrm{wk}\end{array}$ & $\begin{array}{l}\text { Overall } \\
\text { Flock size }\end{array}$ & Range \\
\hline Filtino & 40 & $9.70 \pm 5.1$ & $2.32 \pm 1.32$ & $1.95 \pm 1.1$ & $3.3 \pm 2.6$ & $2.1 \pm 1.2$ & $19.4 \pm 7.0$ & $7-42$ \\
\hline Dalota & 40 & $7.60 \pm 3.9$ & $2.2 \pm 1.30$ & $2.01 \pm 1.7$ & $3.9 \pm 2.5$ & $1.75 \pm 1.2$ & $17.8 \pm 6.6$ & $7-35$ \\
\hline Kaliti & 40 & $10.25 \pm 4.3$ & $3.0 \pm 1.85$ & $2.1 \pm 1.9$ & $3.3 \pm 2.0$ & $1.67 \pm 1.1$ & $20.4 \pm 6.5$ & $9-32$ \\
\hline Gote & 40 & $10.90 \pm 6$ & $2.5 \pm 1.60$ & $1.9 \pm 1.21$ & $5.1 \pm 1.21$ & $1.7 \pm 1.3$ & $22.1 \pm 10.3$ & $5-49$ \\
\hline Overall & 160 & $9.90 \pm 4.98$ & $2.5 \pm 1.50$ & $2.0 \pm 1.3$ & $3.9 \pm 3.5$ & $1.8 \pm 1.2$ & $19.9 \pm 7.9$ & $5-49$ \\
\hline P-value & & 0.058 & 0.082 & 0.955 & 0.083 & 0.483 & 0.105 & \\
\hline
\end{tabular}

Table 1: Flock structure (Mean $\pm \mathrm{SD}$ ) in four kebeles in study areas.

\section{Poultry housing system and facility}

The observations on poultry housing and facilities (Table 2) indicated that $45 \%$ of the respondents in Filtino, $40 \%$ in Kaliti, $30 \%$ in Dalota and $25 \%$ in Gote Kebeles with an overall average of $35 \%$ in study area constructed separate house entirely for poultry which were higher than $14 \%$ reported by Moges et al. [26] in Bure district and $21.2 \%$ by Mengesha et al. [27] in north west Ethiopia, $24.4 \%$ by Fentie et al. [28] in north Gondar and $11.5 \%$ by Tadelle and Ogle [29] village poultry production systems in the central highlands of Ethiopia who have constructed separate shelter for their bird. In contrary, Mekonnen [18] reported that there were no specific separate poultry houses in Dale Wereda. The overall average for separate poultry housing and facilities under this study was significantly lower than 91.1\% in Ada'a and 95.6\% in Lume districts [17] and 90\% in Bhandara district of India [16], reported of backyard chicken owners provided separate poultry house. However, the present observation for Filtino Kebele (45\%) is nearly similar to the report of $48 \%$ in Metekel zone, Northwest Ethiopia [30]. This significant variation might be associated to the farmers' awareness to the importance of poultry housing.

Among the households who have no separate poultry houses, about $15.0 \%, 35.0 \%, 17.5 \%, 27.5 \%$ of the respondents in Filtino, Dalota, Kaliti and Gote kebeles respectively, indicated that their birds perch in the kitchen, and on trees during night time (Table 2). Leta and Bekana [25] reported $1.4 \%$ of the respondents use part of the kitchen and $26.6 \%$ of the chicken perches on tree in Mid Rift Valley of Oromia, Ethiopia. Also there are reports of $58 \%$ and $68 \%$ of the chicken share the main house with family in Mid Rift Valley of Oromia, Ethiopia [25] and in north Gondar [28] respectively, which was higher than the present finding of $24 \%$ under the study area. Lack of knowledge and awareness and poor attention to village chicken production may be some of the reason for not constructing separate chicken house.

\begin{tabular}{|c|c|c|c|c|c|}
\hline \multirow[t]{2}{*}{ Parameter } & \multicolumn{4}{|l|}{ Kebeles } & \multirow{2}{*}{$\begin{array}{l}\text { Overall } \\
\text { Fre (\%) }\end{array}$} \\
\hline & $\begin{array}{l}\text { Filtino } \\
\text { Fre (\%) }\end{array}$ & $\begin{array}{l}\text { Dalota } \\
\text { Fre (\%) }\end{array}$ & $\begin{array}{l}\text { Kaliti } \\
\text { Fre (\%) }\end{array}$ & $\begin{array}{l}\text { Gote } \\
\text { Fre (\%) }\end{array}$ & \\
\hline \multicolumn{6}{|l|}{ Poultry house } \\
\hline $\begin{array}{l}\text { Share same house } \\
\text { with people }\end{array}$ & $5(12.5)$ & $9(22.5)$ & $12(30.0)$ & $13(32.5)$ & $39(24.4)$ \\
\hline Night shelter only & $6(15.0)$ & $14(35.0)$ & $7(17.5)$ & $11(27.5)$ & $38(23.8)$ \\
\hline Separate house & $18(45.0)$ & $12(30.0)$ & $16(40)$ & $10(25.0)$ & $56(35.0)$ \\
\hline With other animals & $11(27.5)$ & $5(12.5)$ & $5(12.5)$ & $6(15.0)$ & $27(16.9)$ \\
\hline \multicolumn{6}{|l|}{ Litter materials } \\
\hline Teff straw & $12(30.0)$ & $8(20.0)$ & $9(22.5)$ & $11(27.5)$ & $40(25.0)$ \\
\hline Teff and wheat straw & $6(15.0)$ & $3(7.5)$ & $4(10.0)$ & $3(7.5)$ & $16(10.0)$ \\
\hline No litter & $22(55.0)$ & $29(72.5)$ & $27(67.5)$ & $26(65.0)$ & $104(65)$ \\
\hline
\end{tabular}

Table 2: Poultry housing system and facility used in the study area.

\section{Poultry feeding practices}

The results for feeding practices (Table 3) revealed that an overall of $70 \%$ of the respondents in study area practice scavenging system with supplementary feeding which was not in agreement with $97.8 \%$ reported by Desalew et al. [17] in East Shewa; $95 \%$ by Asefa [22] in Hawassa zuria; $99 \%$ by Halima [21] in North West Ethiopia; $97.5 \%$ by Moges et al. [26]; $98 \%$ by Mengesha et al. [27] and $92.5 \%$ by Zewdu et al. [30] in Metekel zone, backyard chicken owners provide additional supplement. 
Citation: Weyuma H, Singh H, Megersa M (2015) Studies on Management Practices and Constraints of Back Yard Chicken Production in Selected Rural Areas of Bishoftu. J Veterinar Sci Technol S12: S12-003. doi:10.4172/2157-7579.1000S12-003

Page 4 of 9

\begin{tabular}{|c|c|c|c|c|c|}
\hline \multirow[t]{2}{*}{ Variable category } & \multicolumn{5}{|l|}{ Kebeles } \\
\hline & $\begin{array}{l}\text { Filtino } \\
(\mathrm{N}=40) \\
\text { Fre }(\%)\end{array}$ & $\begin{array}{l}\text { Dalota } \\
(\mathrm{N}=40) \\
\text { Fre }(\%)\end{array}$ & $\begin{array}{l}\text { Kaliti } \\
(\mathrm{N}=40) \\
\text { Fre }(\%)\end{array}$ & $\begin{array}{l}\text { Gote } \\
(\mathrm{N}=40) \\
\text { Fre }(\%)\end{array}$ & $\begin{array}{l}\text { Cumulative } \\
(\mathrm{N}=160) \\
\text { Fre }(\%)\end{array}$ \\
\hline \multicolumn{6}{|l|}{ Feeding method } \\
\hline Only scavenging & $11(27.5)$ & $12(30.0)$ & $9(22.5)$ & $16(40)$ & $48(30.0)$ \\
\hline Scavenging with supplement & $29(72.5)$ & $28(70.0)$ & $31(77.5)$ & $24(60.0)$ & $112(70.0)$ \\
\hline \multicolumn{6}{|l|}{ Type of supplement } \\
\hline Maize and Frushika & $6(15.0)$ & $5(12.5)$ & $7(17.5)$ & $4(10.0)$ & $22(13.75)$ \\
\hline Food left overand others ${ }^{*}$ & $24(60)$ & $22(55)$ & $24(60)$ & $20(50)$ & $90(56.25)$ \\
\hline \multicolumn{6}{|l|}{ Time of feeding } \\
\hline Morning and Evening & $8(20.0)$ & $6(15.0)$ & $6(15.0)$ & $3(7.5)$ & $23(14.4)$ \\
\hline Morning and afternoon & $11(27.5)$ & $9(22.5)$ & $9(22.5)$ & $12(30)$ & $41(25.6)$ \\
\hline Morning, afternoon and evening & $10(25.0)$ & $13(32.5)$ & $16(40.0)$ & $9(22.5)$ & $48(30.0)$ \\
\hline
\end{tabular}

Table 3: Poultry feeding system in four kebeles under study areas. ${ }^{*}$ Frushika, Maize, sorghum.

About $56.25 \%$ of the respondents in the study area used frushika, maize, sorghum and food leftover as major supplementary feed for their chicken. Mekonnen [18] reported feeding practice of maize (6.3\%), frushika (1.2\%) and frushika (6.3\%) in south part of Ethiopia. This study also revealed that out of $70 \%$ respondents supplementing feed to their chicken about $14.4 \%$ supplements twice a day (usually morning and evening), $25.6 \%$ twice a day in morning and afternoon and $30 \%$ supplement their chicken three times a day usually morning, afternoon and evening (Table 3). According to the report of Mekonnen [18] about $45.6 \%$ of respondents supplement twice a day (usually morning and evening) and only $13.8 \%$ of them provide three times a day.

\section{Poultry watering system}

It is revealed from Table 4 that all respondents used tap water in Dalota (100\%) to their chicken, whereas river water (62.5\%) was the major water source in Kaliti kebeles. On overall basis about $48.13 \%$ used tap water, $33.75 \%$ respondents used river water and $18.13 \%$ respondents used both river and tap water to their chicken in the study area. Higher number of respondents used tap water in Dalota than other kebeles; this indicates the availability of better water infrastructure in Dalota than other kebeles. Leta and Bekana [25] reported use of $66 \%$ tap water which is higher than the present results (48.13\%). However, Leta and Bekana [25] reported $15 \%$ of river water in Mid Rift Valley of Oromia, Ethiopia which is lower than $33.75 \%$ observed in the present study.

The results for watering practices (Table 4) in four kebeles under study, revealed that on overall basis about $48.75 \%$ of respondents in the present study provided water to their chicken with free access which is in agreement with the report from Mid Rift Valley of Oromia, Ethiopia (47\%) [25], but lower than the report in village chicken production from East Shewa, Ethiopia (95.6\%) [17]. Concerning the water drinkers, $55.6 \%$ respondents used plastic containers as water drinkers to their back yard chicken in the study area and agreed with the study conducted in South part of Ethiopia (56\%) [18].

\begin{tabular}{|c|c|c|c|c|c|}
\hline \multirow[t]{2}{*}{ Source and frequency of water } & \multicolumn{5}{|l|}{ Kebeles } \\
\hline & $\begin{array}{l}\text { Filtino } \\
\text { Fre (\%) }\end{array}$ & $\begin{array}{l}\text { Dalota } \\
\text { Fre (\%) }\end{array}$ & $\begin{array}{l}\text { Kaliti } \\
\text { Fre (\%) }\end{array}$ & $\begin{array}{l}\text { Gote } \\
\text { Fre (\%) }\end{array}$ & $\begin{array}{l}\text { Overall } \\
\text { Fre (\%) }\end{array}$ \\
\hline \multicolumn{6}{|l|}{ Source } \\
\hline River water & $19(47.5)$ & $0(0.0)$ & $25(62.5)$ & $10(25.0)$ & $54(33.8)$ \\
\hline Tap water & $5(12.5)$ & $40(100)$ & $5(12.5)$ & $27(67.5)$ & $77(48.1)$ \\
\hline River and Tap water & $16(40.0)$ & $0(0.0)$ & $10(25.0)$ & $3(7.5)$ & $29(18.1)$ \\
\hline \multicolumn{6}{|l|}{ Frequency } \\
\hline Free access & $28(70.0)$ & $21(52.5)$ & $7(17.5)$ & $22(55.0)$ & $78(48.8)$ \\
\hline Morning only & $9(22.5)$ & $16(40.0)$ & $22(55.0)$ & $9(22.5)$ & $56(35.0)$ \\
\hline
\end{tabular}


Citation: Weyuma H, Singh H, Megersa M (2015) Studies on Management Practices and Constraints of Back Yard Chicken Production in Selected Rural Areas of Bishoftu. J Veterinar Sci Technol S12: S12-003. doi:10.4172/2157-7579.1000S12-003

Page 5 of 9

\begin{tabular}{|l|l|l|l|l|l|l|}
\hline Morning and evening & $3(7.5)$ & $3(7.5)$ & $11(27.5)$ & $9(22.5)$ & $26(16.3)$ \\
\hline Facility & $11(27.5)$ & $8(20.0)$ & $7(17.5)$ & $6(15.0)$ & $32(20)$ \\
\hline Broken clay & $21(52.5)$ & $22(55.0)$ & $22(55.0)$ & $24(60)$ & $89(55.6)$ \\
\hline Plastic & $8(20.0)$ & $10(25.0)$ & $11(27.5)$ & $10(25.0)$ & $39(24.4)$ \\
\hline Wooden through &
\end{tabular}

Table 4: Poultry watering system in four kebeles under study area.

\section{Source of chicks}

The results for the sources of chicken procurement (Table 5) revealed that an overall of $21.88 \%$ respondents purchased chickens from private/government hatcheries which were not in agreement with the reports of Desalew et al. [17] in Ada'a (84.4\%) and Lume districts $(80 \%)$ purchased chicks from private hatcheries. This study also revealed that about $52.5 \%$ respondents in Filtino, $47.5 \%$ respondents in both Kaliti and Gote Kebeles and 40\% respondents, in Dalota hatched fertile eggs naturally using broody hen at home with an overall average of $46.87 \%$ respondents, in study area and this finding is not in agreement with Khandait et al. [16] who reported $100 \%$ hatching of eggs naturally at home in backyard poultry production at Bhandara district of India.

\begin{tabular}{|l|l|l|l|l|l|}
\hline $\begin{array}{l}\text { Source of the breed } \\
\text { (Fre (\%)) }\end{array}$ & \multicolumn{5}{|l|}{ Kebeles } \\
\cline { 2 - 6 } & $\begin{array}{l}\text { Filtino } \\
\mathbf{( N = 4 0 )}\end{array}$ & $\begin{array}{l}\text { Dalota } \\
\mathbf{( N = 4 0 )}\end{array}$ & $\begin{array}{l}\text { Kaliti } \\
\mathbf{( N = 4 0 )}\end{array}$ & $\begin{array}{l}\text { Gote } \\
\mathbf{( N = 4 0 )}\end{array}$ & $\begin{array}{l}\text { Overall } \\
\mathbf{( N = 1 6 0 )}\end{array}$ \\
\hline Private hatchery & $8(20.0)$ & $10(25.0)$ & $11(27.5)$ & $6(15.0)$ & $35(21.88)$ \\
\hline $\begin{array}{l}\text { Naturally hatched at } \\
\text { home }\end{array}$ & $21(52.5)$ & $16(40.0)$ & $19(47.5)$ & $19(47.5)$ & $75(46.87)$ \\
\hline $\begin{array}{l}\text { Purchased from local } \\
\text { market }\end{array}$ & $11(27.5)$ & $14(35)$ & $10(25.0)$ & $15(37.5)$ & $50(31.25)$ \\
\hline
\end{tabular}

Table 5: Source of the chicks in four kebeles under study area.

However, only $15.6 \%$ and $20 \%$ respondents hatched fertile eggs naturally at home in Ada'a and Lume districts, respectively as reported by Desalew et al. [17] for village chicken in East Shewa, Ethiopia. In addition this finding also showed that about $27.5 \%, 35 \%, 25.0 \%$ and $37.5 \%$ of respondents in Filtino, Dalota, Kality and Gote Kebeles respectively, with an overall average of $31.25 \%$ purchased their chicken from local market which was not in agreement with Nath et al. [31] who reported that $74.4 \%$ of respondents purchased poultry chicks from the local market in rural tribal areas of Sikkim, India.

\section{Performance characteristics of backyard indigenous chickens}

The performance characteristics of indigenous chickens (Table 6) revealed that overall average age at sexual maturity expressed in terms of age at first egg was observed to be $5.49 \pm 0.8$ month in the study area and age at first egg did not vary significantly between four kebeles under study. This age at first was lower than 6.33 month reported by Meseret [14] in Gomma Wereda, Jimma Zone, Ethiopia, 7.07 months reported by Mekonnen [18] for indigenous chicken in south part of Ethiopia. The average age at first egg observed in the present study was well within the range (4-7 months) for age at first egg reported for indigenous chicken in Mid Rift Valley of Oromia, Ethiopia [25].

This study also revealed that overall average number of clutches/ bird/year were $3.30 \pm 0.5$ with no significant differences between the four kebeles in the study area. These results agreed with Tadelle and Ogle [26], as they have reported 3-4 clutches for indigenous chicken in the central highlands of Ethiopia and Moreki [32] also reported 3-4 clutches for indigenous chicken in Botswana.

The present number of clutches/hen/year under present study was lower than 4.3 clutches reported by Fentie et al. [28], 5-6 clutches reported by Dessie and Ogle [33].

\begin{tabular}{|c|c|c|c|c|c|c|c|}
\hline \multirow[t]{3}{*}{ Parameters } & \multicolumn{4}{|c|}{ Kebeles $(\mathrm{N}=40)$} & \multirow{3}{*}{$\begin{array}{l}\text { Overall Mean } \pm \\
\text { SD }\end{array}$} & \multirow{3}{*}{ Range } & \multirow{3}{*}{ P-Value } \\
\hline & \multirow{2}{*}{$\begin{array}{l}\text { Filtino } \\
\text { Mean } \pm \text { SD }\end{array}$} & \multirow{2}{*}{$\begin{array}{l}\text { Dalota } \\
\text { Mean } \pm \text { SD }\end{array}$} & \multirow{2}{*}{$\begin{array}{l}\text { Kaliti } \\
\text { Mean } \pm \text { SD }\end{array}$} & \multirow{2}{*}{$\begin{array}{l}\text { Gote } \\
\text { Mean } \pm \text { SD }\end{array}$} & & & \\
\hline & & & & & & & \\
\hline $\begin{array}{l}\text { Age at sexual } \\
\text { maturity(month) }\end{array}$ & $5.68 \pm 0.8$ & $5.65 \pm 0.86$ & $5.3 \pm 0.88$ & $5.32 \pm 0.8$ & $5.49 \pm 0.8$ & $4-7$ & 0.75 \\
\hline $\begin{array}{l}\text { Number of eggs laid per } \\
\text { clutch per hen }\end{array}$ & $13.53 \pm 3.9$ & $12.8 \pm 3.3$ & $13.37 \pm 3.2$ & $13 \pm 3.14$ & $13.18 \pm 3.5$ & $7-20$ & 0.799 \\
\hline Number of clutch/hen/year & $3.28 \pm 0.45$ & $3.3 \pm 0.5$ & $3.35 \pm 0.48$ & $3.28 \pm 0.4$ & $3.30 \pm 0.5$ & $3-4$ & 0.873 \\
\hline $\begin{array}{l}\text { Number of eggs laid/hen/ } \\
\text { year }\end{array}$ & $45.1 \pm 10.5$ & $42.65 \pm 9.3$ & $44.95 \pm 8.8$ & $44.15 \pm 10$ & $44.20 \pm 9.6$ & $20-60$ & 0.663 \\
\hline $\begin{array}{l}\text { No. of eggs incubated/ } \\
\text { clutch/hen }\end{array}$ & $11.5 \pm 3.3$ & $10.5 \pm 3.0$ & $10.9 \pm 2.59$ & $10.83 \pm 3.0$ & $10.92 \pm 3.1$ & $6-17$ & 0.454 \\
\hline $\begin{array}{l}\text { No. of eggs hatched/hen/ } \\
\text { year }\end{array}$ & $30.2 \pm 7.3$ & $27.2 \pm 7.0$ & $28.42 \pm 6.2$ & $27.87 \pm 6.0$ & $28.42 \pm 6.7$ & $15-45$ & 0.234 \\
\hline
\end{tabular}


Citation: Weyuma H, Singh H, Megersa M (2015) Studies on Management Practices and Constraints of Back Yard Chicken Production in Selected Rural Areas of Bishoftu. J Veterinar Sci Technol S12: S12-003. doi:10.4172/2157-7579.1000S12-003

Page 6 of 9

\begin{tabular}{|l|l|l|l|l|l|l|l|}
\hline Hatchability (\%) & $75.4 \pm 5.8$ & $71.13 \pm 5.0$ & $70.9 \pm 5.1$ & $70.7 \pm 5.0$ & $72.10 \pm 5.5$ & 5785.7 & $<0.001$ \\
\hline $\begin{array}{l}\text { No. of chicken raised/ } \\
\text { year/hen }\end{array}$ & $22.8 \pm 5.9$ & $19.5 \pm 5.27$ & $20.13 \pm 4.5$ & $19.75 \pm 5.0$ & $20.53 \pm 5.3$ & $10-33$ & 0.015 \\
\hline Mortality (\%) & $24.8 \pm 4.8$ & $28.38 \pm 4.2$ & $29.69 \pm 4.3$ & $27.2 \pm 3.9$ & $27.52 \pm 4.7$ & $14-40$ & $<0.001$ \\
\hline Survivability of chicks (\%) & $74.7 \pm 4.7$ & $71.62 \pm 4.2$ & $70.49 \pm 4.2$ & $73 \pm 3.99$ & $72.45 \pm 4.5$ & $60-85.7$ & $<0.001$ \\
\hline
\end{tabular}

Table 6: Performance characteristics of backyard indigenous chickens in the study area.

The overall average number of eggs laid/clutch/hen (clutch size) were observed to be $13.18 \pm 3.5$ eggs in the study area with nonsignificant variations between the different four kebeles under study. This average number of eggs/clutch/hen was lower than 15.1 eggs/ clutch/hen reported by Fentie et al. [28] in North Gondar which could be due to the more number of clutches ( 4.3 clutches) reported by the same researcher.

The overall mean number of eggs laid per hen per year was recorded to be $44.20 \pm 9.6$ eggs with the range of 20-60 eggs per year in 3-4 clutches in the present finding. These averages for egg production and number of clutches were lower than annual production of 55-80 eggs per year in 5-6 clutches Dessie and Ogle [33]. However, the recorded value on egg production/hen/year in present study agreed with Barua and Yoshimura [34] as they have reported 44 eggs for Bangladesh; Ssewannyana et al. [20] reported 40 -50 eggs for Uganda for the village chicken production; Fikre [35] reported 36-42 for Ambo wereda and Tadelle and Ogle [36] reported 40-60 egg for the central highlands of Ethiopia.

The average number of eggs incubated/hen at a time was found to be $10.92 \pm 3.1$ with non-significant variations between the averages observed for four kebeles (Table 6). The average number of eggs incubated/hen at a time under present study is lower than $13.2 \pm 1.8$ eggs reported by Fentie et al. [28] in Small-scale family poultry production in North Gondar. The mean percent hatchability (Table 6) observed for the four kebeles revealed the highest hatchability of 75.4 $\pm 5.8 \%$ in Filtino, followed by $71.13 \pm 5.0 \%$ in Dalota, $70.9 \pm 5.1 \%$ in Kaliti and $70.7 \pm 5.0 \%$ in Gote kebeles where significantly different from each other. The differences in hatchability between four kebeles could be attributed to the season of the year, since hatchability of eggs is affected by season of incubation and agreed with Kitalyi [37]. The overall average hatchability in the present study was observed to 72.10 $\pm 5.5 \%$ which is closer to hatchability of $75 \%$ reported by Wilson [5].
However, the present hatchability estimate was lower than $84.6 \%$ reported by Fentie et al. [28] in small-scale family production in North Gondar, 82\% hatchability reported by Kusina et al. [38] in Zimbabwe, $80.9 \%$ hatchability reported by Tadelle and Ogle [36] for Central highlands of Ethiopia and $89.1 \%$ reported by Mekonnen [18] for south part of Ethiopia.

The mean percent chicks mortality (to an age of 8 weeks) of the backyard chicken in this survey showed significant differences $(\mathrm{P}<0.05)$ between kebeles. Accordingly, an overall survivability of chicks was found $72.5 \pm 4.5 \%$ with significant differences between the study areas. The significant variation in mortality and survivability of chicken between kebeles could be attributed to the season of hatching the chicks, incubation and brooding facilities provided to the broody and measures of protection from predators and scavengers taken by the respondents. The overall mean mortality was found to be $27.5 \pm$ $4.7 \%$ in the present study was comparable to the mortality reported in Uganda (25\%) by Ssewannyana et al. [20] for village chickens in backyard system. However, chick mortality up to 8 weeks of age in the present study was lower than $61 \%$ reported by Tadelle and Ogle [36] from the central highlands of Ethiopia; $55 \%$ by Mekonnen [18] from Dale wereda and $93 \%$ by Brännänng and Pearson [39] from Assela.

\section{Poultry healthy management and source of chicken}

Table 7 revealed that an overall average of $36.87 \%$ respondents practiced use of anti-ectoparasites in the present study. This average was lower than $49.6 \%$ by Khandait et al. [16] in backyard poultry rearing practices at Bhandra district of Maharashtra, used antiectoparasites. Village poultry keeping farmers tend to start dealing with disease control once the symptoms appear in their flocks. They therefore treat symptoms instead of diseases and link specific therapeutic preparations to specific disease symptoms [40].

\begin{tabular}{|c|c|c|c|c|c|}
\hline \multirow[t]{2}{*}{ Variable category } & \multicolumn{5}{|l|}{ Kebeles } \\
\hline & $\begin{array}{l}\text { Filtino } \\
(\mathrm{N}=40) \text { Fre }(\%)\end{array}$ & $\begin{array}{l}\text { Dalota } \\
(\mathrm{N}=40) \\
\text { Fre }(\%)\end{array}$ & $\begin{array}{l}\text { Kaliti } \\
(\mathrm{N}=40) \\
\text { Fre }(\%)\end{array}$ & $\begin{array}{l}\text { Gote } \\
(\mathrm{N}=40) \\
\text { Fre }(\%)\end{array}$ & $\begin{array}{l}\text { Overall }(\mathrm{N}=160) \\
\text { Fre }(\%)\end{array}$ \\
\hline \multicolumn{6}{|c|}{ Application of anti ectoparasite } \\
\hline No & $28(70.0)$ & $27(67.5)$ & $22(55.0)$ & $24(60.0)$ & 101(63.13) \\
\hline Yes & $12(30.0)$ & $13(37.5)$ & $18(45.0)$ & $16(40.0)$ & $59(36.87)$ \\
\hline \multicolumn{6}{|l|}{ Culling practice } \\
\hline No & $12(30.0)$ & $15(37.5)$ & $15(37.5)$ & $12(30.0)$ & $54(33.75)$ \\
\hline
\end{tabular}


Citation: Weyuma H, Singh H, Megersa M (2015) Studies on Management Practices and Constraints of Back Yard Chicken Production in Selected Rural Areas of Bishoftu. J Veterinar Sci Technol S12: S12-003. doi:10.4172/2157-7579.1000S12-003

Page 7 of 9

\begin{tabular}{|l|l|l|l|l|l|}
\hline Yes & $28(70.0)$ & $25(62.5)$ & $25(62.5)$ & $28(70.0)$ & $106(66.25)$ \\
\hline
\end{tabular}

Table 7: Use of anti-ectoparasites and culling practice and in the study area

Purposeful culling of chickens (Table 7) was practiced by an overall average of $66.3 \%$ respondents in the present study due to various reasons like sickness, poor productivity and old age which is lower than $88.75 \%$ reported by Atsbeha [41] in central zone of Tigray; $100 \%$ reported by Desalew et al. [17] in East Shewa, Ethiopia and $86.9 \%$ reported by Mekonnen [18] in south part of Ethiopia. It was also observed that none of the respondents vaccinated their birds against any disease in four kebeles under study area (Table 8). This observation was in agreement with Leta and Bekana [25]; Khandait et al. [16]; Moges et al. [26]; Mengesha et al. [27] and Takele and Oli [42] as they all have reported that none of the backyard poultry owner practiced vaccination of birds against poultry diseases in different areas of their study. However, Vaccination has been practiced in Lume and Ada'a districts and this was due to the tremendous and coordinated efforts of livestock experts, development agents (DAs) and field veterinarians in both districts Desalew et al. [17].

\begin{tabular}{|c|c|c|c|c|c|}
\hline \multirow[t]{2}{*}{ Constraints } & \multicolumn{5}{|l|}{ Kebeles } \\
\hline & $\begin{array}{l}\text { Filtino } \\
(\mathrm{N}=40) \\
\text { Fre }(\%)\end{array}$ & $\begin{array}{l}\text { Dalota } \\
(\mathrm{N}=40) \\
\text { Fre }(\%)\end{array}$ & $\begin{array}{l}\text { Kaliti } \\
(\mathrm{N}=40) \\
\text { Fre }(\%)\end{array}$ & $\begin{array}{l}\text { Gote } \\
(\mathrm{N}=40) \\
\text { Fre }(\%)\end{array}$ & $\begin{array}{l}\text { Overall } \\
(\mathrm{N}=160) \\
\text { Fre }(\%)\end{array}$ \\
\hline Presence of disease & $16(40.0)$ & $19(47.5)$ & $12(30.0)$ & $14(35.0)$ & $61(38.1)$ \\
\hline Predators & $10(25.0)$ & $6(15.0)$ & $13(32.5)$ & $8(20.0)$ & $37(23.1)$ \\
\hline Inadequate veterinary service & $7(17.5)$ & $5(12.5)$ & $5(12.5)$ & $6(15.0)$ & $23(14.4)$ \\
\hline Lack of knowledge in poultry rearing & $4(10.0)$ & $4(10.0)$ & $3(7.5)$ & $7(17.5)$ & 18(11.3) \\
\hline Feed shortage & $3(7.5)$ & $6(15.0)$ & $7(17.5)$ & $5(12.5)$ & $21(13.1)$ \\
\hline
\end{tabular}

Table 8: Major constraints of poultry production in the study area

The most prevalent disease signs as perceived by the respondents in the four kebeles were decreased or loss of appetite, watery and yellowish droppings, paralysis and, consequently, death. This syndrome was called 'fengle' by the community in the study area. This disease, which was probably Newcastle disease, was an acute condition, lasting for only 3-5 days, and usually resulted in the death of the whole flock because transmission was very rapid. Outbreaks of this disease usually occurred at the beginning of the rainy season, that is at the end of May and beginning of June, but after villagization it became a problem throughout the year, even though it was still more serious at the beginning of the rainy season. The farmers did not have any preventive medicine or practice for this fatal disease and only treat their birds with accepted traditional medicines after the start of an outbreak. Similarly, Desalew et al. [17] and Meseret [14], Mekonnen [18]; Moges et al. [26] and Serkalem et al. [44] reported Newcastle disease as economically important diseases in North West Ethiopia. Survey from Tanzania indicated that Newcastle is the most devastating disease in village chickens [45].

On the other hand overall average of $23.1 \%$ respondents complained the presence of predators in the study area which is higher than $12 \%$ respondents complained the presence of predators reported by Desalew et al. [17] in East Shewa, Ethiopia. However, the present estimate was lower than $89.17 \%$ of the poultry owners facing the

\section{General constraints on traditional backyard poultry production}

Information collected on constraints in back yard poultry production (Table 8) revealed that disease was the most important problem affecting poultry productivity with an overall average of $38.1 \%$ disease incidence in the study area and agreed with the reports of Aini [43] as he has also observed that in the free-range and backyard poultry production system, diseases are the major limiting factor to the production of backyard chickens. This disease incidence was higher than $33.1 \%$ incidence of disease reported by Desalew et al. [17] in East Shewa, Ethiopia. However, the present disease incidence was lower than $100 \%$ higher incidence of disease reported by Khandait et al. [16] in Bhandara district of Maharashtra (India). problem of attack of predator's reported by Khandait et al. [16] in Bhandara district of Maharashtra (India). Predation was reported to be highest in the rainy season because of the high density of vegetation, which attracted and provided cover for predator animals. Common predators were dogs, cats (domestic or wild), eagles, hawk and vultures in this study agreed with Khandait et al. [16].

Other constraints include inadequate veterinary services, feed shortage and lack of poultry production knowledge in the study area. Limited veterinary services for village chickens were also reported by Moges et al. [26] in North West Ethiopia, Leta and Bekana [25]; Takele and Oli [42] and Mengesha et al. [27] in different parts of Ethiopia. Lack of poultry production knowledge was the other constraint in all kebeles and agreed with the report of Moges et al. [26] in Ethiopia and Khandait et al. [16] in India.

\section{Conclusion}

Backyard chicken production is playing an important role in increasing socio-economic status of rural community and employment in rural areas. However the backyard chickens suffer low productivity and high mortality. Disease control and improved management in backyard chicken production are lacking in the study area. Diseases followed by predation were found to be the major 
constraint of backyard chicken production in rural area of Bishoftu. Interventions to improve backyard chicken production could have considerable benefits. This could considerably reduce the losses and maximize the returns which in turn increase off-take rates whether for home consumption or for sale. Therefore animal husbandry and health extension service units should be strengthened to train chicken farmers to increase the level of awareness and benefits from backyard birds. Furthermore, improvements in management by provision of feed and clean water to young chicks, indoor management of chicken and control of diseases and predators and improving the genetic potential should also be promoted. Vaccination schemes should be developed by availing vaccines and training to community vaccinators to carry out vaccinations at kebeles level in a wide coverage.

\section{Acknowledgement}

The authors highly acknowledge farmers of the study area for their willingness and cooperation during this survey.

\section{References}

1. Alemu Y Tadelle D (1997) The status of poultry research and development in Ethiopia, research bulletin No.4, poultry commodity research program Debre Zeit agricultureal center. Haramaya University of agriculture, Ethiopia, p. 62.

2. Sonaiya E Swan S (2005) Small-scale poultry production, technical guide manual, FAO Animal Production and Health Nol. Food and Agriculture Organization (FAO), Rome.

3. Branckaert RDS, Gaviria L, Jallade J, Seiders RW (2000) Transfer of technology in poultry production for developing countries. SD dimension.

4. Atunbi OA, Sonaiya EB (1994) An assessment of backyard poultry housing in Osogbo, Osun State, Nigeria. African Network for Rural Development Newsletter 4: 73-75.

5. Wilson RT (2010) Poultry production and performance in the Federal Democratic Republic of Tanzania. World's Poultry Science Journal 66: 441-453.

6. Tadelle D, Million T, Alemu Y, Peters K (2003) Village chicken production systems in Ethiopia: flock characteristics and performance; Livestock Research for Rural Development 15: 1.

7. Central Statistical Agency (CSA) (2013) Agricultural sample survey 2012/13. Report on livestock and livestock characteristics, Statistical Bulletin Addis Ababa, Ethiopia, 2: 570.

8. Dana N, Duguma R, Teklewold H, Aliye S (2006) Transforming village poultry systems into small agro-business ventures: a partnership model for the transfer of livestock technologies in Ethiopia. Livestock Research for Rural Development 18: 169.

9. Alemu Y, Tadelle D (1997) The status of poultry research and development in Ethiopia, research bulletin No 4, poultry commodity research program Debre Zeit Agricultural Center. Alemaya University of Agriculture, Ethiopia, p. 62.

10. Solomon D (2007) Suitability of hay-box brooding technology to rural household poultry production system, Jimma, Ethiopia. Livestock Research for Rural Develoment 19: 1.

11. Pederson CV, Kristensen AR, Madsen J (2001) On-farm research leading to a dynamic model of traditional chicken production systems. Department of Animal Science and 86 Animal Health's, the Royal Veterinary and Agricultural University.2 Groennegardsverj, DK-1870 Frederiksberg C, Denmark.

12. ADARDO (2007) Ada'a District Agricultural and Rural Development office.

13. Conway DP Mckenzie ME (2007) Poultry coccidiosis and effect of coccidiosis diagnostic and testing procedures (3rdedn) Ames, Iowa: Black publishing.
14. Meseret MB (2010) Characterization of village chicken production and marketing system in Gomma wereda, Jimma Zone, Ethiopia. M.Sc. thesis presented to school of graduate studies of Jimma University, Ethiopia, pp. 1-65.

15. Muchadeyi FC, Wollny CB, Eding H, Weigend S, Makuza SM, et al. (2007) Variation in village chicken production systems among agroecological zones of Zimbabwe. Trop Anim Health Prod 39: 453-461.

16. Khandait VN, Gawande SH, Lohakareand AC, Dhenge SA (2011) Adoption level and constraints in backyard poultry rearing practices at Bhandara district of Maharashtra (India). Research Journal of Agricultural Science 2: 110-113.

17. Desalew T, Harpal S, Ashenafi M, Wondimeneh E, Tadelle D (2013) Study on management practices and marketing system of village chicken in East Shewa, Ethiopia. African Journal of Agricultural research 8: 2696-2702.

18. Mekonnen $\mathrm{G}$ (2007) Characterization of small holder poultry production and marketing system of Dale, Wonsho and Loka Abaya weredas of Southern Ethiopia. MSc thesis. Presented to school of graduated studies of Haramaya University. Pp: 1-80.

19. Eugene F (2004) A longitudinal analysis of chicken production systems of smallholder farmers in Leyte, Philippines. Leyte State University, Leyte, the Philippines.

20. Sewannyana E, Ssali AT, Kasadha T, Dhikusooka MK, Kalema P (2004) Characterization of indigenous chickens of Uganda, Kampala, Uganda p. 63.

21. Halima H (2007) Phenotypic and genetic characterization of indigenous chicken populations in Northwest Ethiopia. PhD Thesis, University of the Free State, Bloemfontein, South Africa. Pp: 186.

22. Asefa $\mathrm{T}$ (2007) Poultry management practices and on farm performance evaluation of Rhode Island Red (RIR), fayoumi and local chicken in Umbullo Wachu Watershed. M.Sc.thesis. Department of Animal and Range Sciences, Hawassa College Of Agriculture, Hawassa, Ethiopia.

23. Khalafalla SWH (2000) Village poultry production in Sudan. Department of Microbiology, Faculty of Veterinary Science, University of Khartoum, North Sudan.

24. Yakubu A (2010) Indigenous chicken flocks of Nasarawa State, Nigeria: their characteristics, husbandry and productivity. Tropical and Subtropical Agro-ecosystems 12: 69-76.

25. Leta S, Bekana E (2010) Survey on village based chicken production and utilization system in Mid Rift Valley of Oromia, Ethiopia. Global Veterinaria 5: 198-203.

26. Moges F, Abera M, Tadelle D (2010) Assessment of village chicken production system and evaluation of the productive and reproductive performance of local chicken ecotype in Bure district, North West Ethiopia. Ajar 5: 1739-1748.

27. Mengesha M, Tamir B, Dessie T (2011) Village chicken constraints and traditional management practices in Jamma District, South Wollo, Ethiopia. Livestock research for rural development 23: 37.

28. Fentie T, Abbeb B, Kassa T (2013) Small-scale family poultry production in North Gondar: characteristics, productivity and constraints. LRRD 25: 161.

29. Dessie T, Ogle B (2001) Village poultry production systems in the central highlands of Ethiopia. Trop Anim Health Prod 33: 521-537.

30. Zewdu S, Kassa B, Agza B, Alemu F (2013) Village chicken production systems in Metekel zone, Northwest Ethiopia. Wjar 2: 256 -262.

31. Nath BG, Toppo S, Chandra R, Chatlod LR, Mohanty AK (2012) Level of adoption and constraints of scientific backyard poultry rearing practices in rural tribal areas of Sikkim, India. OJAFR 2: 2228-7701.

32. Moreki JC (2010) Village poultry production in Serowe-Palapye SubDistrict of Botswana.LRRD 22: 3 .

33. Dessie T1, Ogle B (2001) Village poultry production systems in the central highlands of Ethiopia. Trop Anim Health Prod 33: 521-537.

34. Barua A, Yoshimura Y (2005) Rural poultry keeping in Bangladish. wpsr 53: 387-394. 
Citation: Weyuma H, Singh H, Megersa M (2015) Studies on Management Practices and Constraints of Back Yard Chicken Production in Selected Rural Areas of Bishoftu. J Veterinar Sci Technol S12: S12-003. doi:10.4172/2157-7579.1000S12-003

Page 9 of 9

35. Fikre A (2000) Base line data on chicken population, productivity, husbandry, feeding and constraints in four peasant associations in Ambo wereda, Department of Animal Sciences. Ambo College of Agriculture, Ambo, Ethiopia.

36. Tadelle D, Ogle B (1996) Studies on scavenging poultry production systems in Central highlands of Ethiopia. MSc. Thesis presented Swedish University of Agricultural Sciences. Pp. 22-70.

37. Kitalyi AJ (1998) Village chicken production systems in rural Africa Household food security and gender issue, FAO. Rome, Italy pp: 160.

38. Kusina JF, Kusina NT, Mhlanga F (2001) A survey on village chicken losses: Causes and solutions as perceived by farmers RG Alders and PB Sparrow (Ed), Proceedings of SADC planning workshop on Newcastle disease control in village chickens, Maputo, Mozambique,6-9 March 2000. ACIAR 103: 148-155.

39. Brannang E, Pearson S (1990) Ethiopian animal husbandry, Uppsala, Sweden. Breeding in the Tropics and Sub-tropics, Humboldt University of Berlin, Germany. p. 127.
40. Gueye EF (2002) Family poultry research and development in low income food deficit countries: Approaches and prospects. Outlook on agriculture 31: 13-21.

41. Atsbeha AT (2013) Rural poultry production and health management practices in Central zone of Tigray, Ethiopia. SJAS 2: 340-354.

42. Desta TT, Wakeyo O (2012) Uses and flock management practices of scavenging chickens in Wolaita Zone of southern Ethiopia. Trop Anim Health Prod 44: 537-544.

43. Aini I (1990) Indigenous chicken production in South-East Asia. World's Poultry Science 46: 51-57.

44. Serkalem T, Hagos A, Zeleke A (2005) Sero-prevalence study of newcastle disease in local chickens in Central Ethiopia. IJARVM 3: 1.

45. Yongolo MGS (1996) Epidemiology of Newcastle disease in village chickens in Tanzania. 